\title{
Design, Fabrication and Performance Evaluation of a Manual Clay Brick Moulding Machine
}

\author{
S.K. Kolawole ${ }^{1,3}$ and J.K. Odusote ${ }^{2, *}$ \\ ${ }^{I}$ Mechanical Engineering Department, Federal Polytechnic, Offa, Kwara state \\ ${ }^{2}$ Materials and Metallurgical Engineering, University of Ilorin, Ilorin, Nigeria \\ ${ }^{3}$ Mechanical Engineering Department, University of Ilorin, Ilorin, Nigeria
}

Received 29 November 2012; Accepted 20 February 2013

\begin{abstract}
In an attempt to improve the production of clay bricks for housing and general construction purposes, a $215 \mathrm{X} 102.5 \mathrm{X}$ $65 \mathrm{~mm}$ manual brick moulding machine was designed and fabricated. The machine parts were made of mild steel, because of its availability and versatile machinability. The efficiency of the machine was examined using local clay, sourced within the University of Ilorin, Ilorin, Nigeria. Water was added to the clay after sieving to form a paste, and then packed into a mould box, before manually rammed and compacted with the machine mould cover. This process allowed for the formation of required shape, which was sent to kiln for baking to obtain stronger bricks. The machine is capable of producing a total of four bricks at a time using the available four mould boxes. The production time of the four bricks was found to be relatively equal to the time used by an automated one to produce equal number of bricks, indicating favourable efficiency. Thus, the fabricated manual machine can be used for mass production of clay bricks for improved and effective housing delivery.
\end{abstract}

Keywords: Clay Brick, Housing, Mild steel, Moulding machine, Manual

\section{Introduction}

Building construction has become complex and sophisticated nowadays. Early types of construction provided minimal shelter from wind, fire attack and rain. Modern day housing provides not just only shelter but a total internal environment where every aspect of security, climate and lightning can be under finger-tip control. With this development, there is continuous demand for improved, more efficient and economical as well as environmental friendly construction materials such as baked clay bricks.

Bricks can be made of clay or a mixture of sand and cement, but the latter is widely used for building houses in most of the developing countries like Nigeria. However, modern construction work, such as structural design and construction, building, architectural design and some other industrial applications [5], requires proper selection of materials. Hence, modern brickwork represents a highly complex undertaking planned down to the last detail and completely rationalised in operation [5]. This means that before the realisation of such project, careful planning is required to ensure profitability, proper materials selection and operational efficiency in order to minimise investment risk [2]. The economic realities in many developing countries like ours call for development of least-cost brick making techniques, which will be readily available for both in rural and urban areas. In addition, the epileptic power

*E-mail address :jamiukolawole@gmail.com ISSN: 1791-2377 @ 2013 Kavala Institute of Technology. All rights reserved. supply in most of these countries makes the manual machine more appropriate. Hence, without compromising on standards and quality, durable and versatile building material, such as brick, produced at the most economical price using locally fabricated machine is very essential for housing delivery in this part of the world. Bricks exist in different shapes, sizes, colours and their applicability depends on all these factors including the raw materials used in their production [2].

In some developed countries like the United States, there are some laws called Building Acts or Building Codes enacted to primarily set standards for new constructions and also to prevent continued use of buildings that are deficient in some basic requirements such as fire resistant and general safety [8]. Hence, manufacturers of building materials these days have continued to experiment with their products to allow for relatively durable and inexpensive materials that will be compliant with these regulations.

A developing country like Nigeria needs to imbibe this culture too, at least to reduce the incessant cases of building collapses in almost all parts of the country. Apart from the substandard building materials, such as a poorly reinforced concrete and steel, which resulted into collapse of buildings, other major cause of collapses is fire outbreak [1]. Thus, the use of clay bricks will substantially reduce building collapses resulting from fire outbreak, because this brick usually becoming stronger when baked in fire.

As shown in Fig. 1, clay bricks may be arranged in stacks in a building wall. They stand better test of time and require even lesser amount of concrete mix than the 
conventional blocks [7]. They also require no plastering when used in buildings.

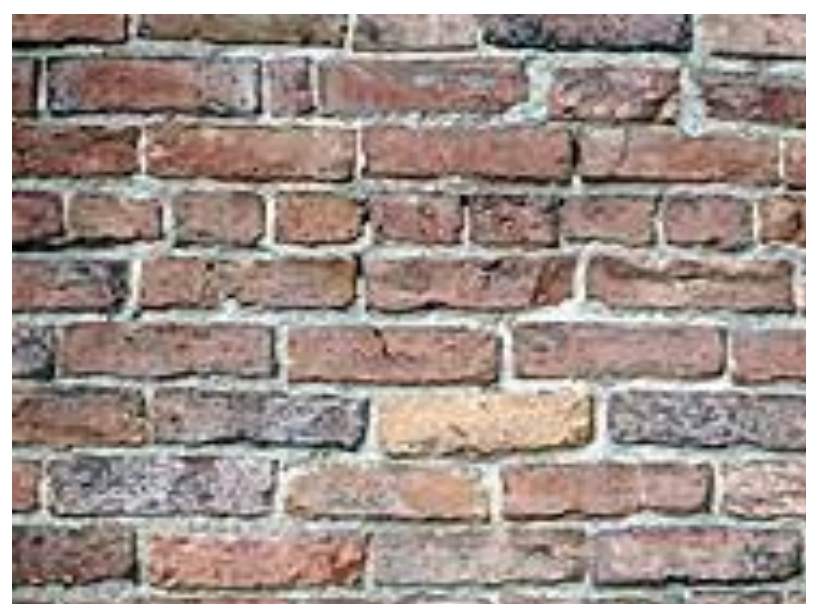

Fig.1. Brick wall used for construction [7].

Clay bricks are generally stronger, more durable and are exceptionally less prone to fire attacks all of which means they can withstand the most severe service conditions in building applications and other engineering structures [5]. Clay bricks can be used for external and internal load bearing walls, partition walls, building foundations, floorings and construction pavings [6], where they could serve as suitable and even better replacements for concrete blocks. In the present study, brick production output is improved from one (1) to four (4) using rectangular $215 \mathrm{X}$ 102.5 X $65 \mathrm{~mm}$ mould box with four compartments. This is aimed at improving the local production and the use of clay bricks for building and other general construction purposes in replacement of conventional concrete blocks, which are more expensive and less protective against fire outbreak.

\section{Materials and methods}

The design, machining and construction of the brick moulding machine parts were carried out at the University of Ilorin, Ilorin, Nigeria. The facilities at the machining, fitting, and welding sections of the Mechanical Engineering workshop were used for the construction of the machine and those at the Civil Engineering workshop were used for the production of the bricks. The material used for the machine parts is mild steel (rods, angle bars and plates), which was bought at scrap metal market in Ilorin metropolis. Design calculations of the mould box compartments, the linkage mechanisms that transmit motion to the mould boxes for the ejection of the wet bricks, the machine frame that support the bulk of the entire structure and the lever arm that lifts the ejector mechanism were carried out prior to fabrication. Clayey soil collected from University of Ilorin Engineering complex was first baked to extract any water moisture that might be trapped. The baked soil was then sieved using a mesh size of $10 \mu \mathrm{m}$. Mixtures of $20 \mathrm{~kg}$ of sieved soil plus 3 $\mathrm{kg}$ of cement were packed in a bowl and thoroughly mixed with 10 litres of water added to form the mortar into paste. The cement was added to act as a binder. Mixing was done for about 15 minutes with a trowel and the mixture was packed into the mould boxes compartment for ramming using the mould cover to compact to size. After proper ramming, clay bricks were ejected and first laid out in the sun for about 17 hours. This was followed by transferring of the dry bricks to a coke-fired furnace set at $85^{\circ} \mathrm{C}$ for about 3 hours to dry the remaining moisture. The baked bricks were then placed in a basin of water for 2 days to ensure adequate curing, in order to increase their hardness [5]. The weight of a single brick was checked using a weighing balance and found to be $7.4 \mathrm{~kg}$, which is a reasonable value compared with the design calculation. Although, there are many property tests such as water absorption property, bulk density measurement, hardness, soundness property that could be carried out on the baked bricks to ascertain their durability but only the soundness test was carried out in the present study due to facilities constraint. This test was carried out by dropping the moulded clay bricks on concrete floor from a height of about 2 meters, and they gave clear ringing sound without fracturing or breaking, which confirms its soundness and hardness.

\subsection{Design calculations for the brick-moulding machine design of mould box compartments}

The number of mould box compartment is four (4). The dimension of each compartment is 216 X $103 \mathrm{X} 66 \mathrm{~mm}$. Resistant to failure by buckling was designed for in each of the mould cavities. For occurrence of buckling, the critical load is given by [4]:

$\operatorname{Pcr}=\mathrm{C} \pi 2 \mathrm{EI} / \mathrm{L} 2$

where Pcr $=$ critical load (the weight of the wet bricks must not be up to this), $\mathrm{E}=$ Modulus of Elasticity of mild steel = $210 \mathrm{X} 109 \mathrm{~N} / \mathrm{m} 2, \mathrm{C}=$ constant depending on end conditions, i.e. either fixed of free, $\mathrm{I}=$ Second moment of area, and $\mathrm{L}=$ length of each mould box compartment. Note: The target here is to compute value of load (force exerted by wet bricks) to ensure it does not exceed the critical load, Pcr.

\subsection{Design for linkage mechanism.}

The twisting movement of the solid rod through the $25 \mathrm{~mm}$ diameter (D) hole in the linkage mechanism calls for the design of the system to resist torsional loading.

The torsional deflection $\Theta$ on a solid section is given by the relation [3]:

$$
\Theta=32 \mathrm{LT} / \pi \mathrm{D} 4
$$

where $\mathrm{T}=$ torque $(\mathrm{Nm}), \mathrm{L}=$ length of the $\operatorname{rod}$ and $\mathrm{G}=$ Modulus of rigidity $=8 * 1010 \mathrm{~N} / \mathrm{m} 2$. Angular displacement $\Theta$, is measured when the linkage is at acute position (not transmitting any motion) and obtuse position (at position when load is ejected)

\subsubsection{Design for the machine frame}

For the frame to be able to carry the enormous weight of the deflection, it must withstand deflection due to shock loading of the machine during the process of ramming and/or compacting. This calls for the stiffness of the members. By stiffness, the measure of resistance of a component or machine member to deflection is accounted for.

Load that may cause deflection of the members was calculated using [3]:

$\mathrm{Y}=\mathrm{FL} 3 / 3 \mathrm{EI}$ 
where $\mathrm{Y}=$ deflection of the component members, $\mathrm{F}=$ applied load (weight of machine + weight of wet bricks), $\mathrm{E}=$ Modulus of Elasticity of mild steel, and I = Second moment of area.

\subsubsection{Design of the welded joints}

Arc welding was used for welding parts joined. Tensile strength of the joints was calculated for using the relations [4]:

$$
\mathrm{P}=\mathrm{t} * \mathrm{~L} * \delta \mathrm{t}
$$

where $\mathrm{P}=$ applied load on the joint $(\mathrm{N}), \mathrm{t}=$ thickness of joint $(\mathrm{mm}), \mathrm{L}=$ length of the welded joint $(\mathrm{mm})$, and $\delta \mathrm{t}=$ strength of the joint $(\mathrm{N} / \mathrm{mm} 2)$

\subsection{The fabrication process}

The processes entailed are as highlighted below:
a) Measuring, marking out and cutting of the various parts of the mild steel
b) Bolts, nuts and stud machining
c) Holes formation
d) Joining of machined parts
e) Finishing and aesthetics

\subsubsection{Machine diagrams.}

Figures 2 and 3 show the diagrams of the fabricated brick moulding machine after components design, fabrication and coupling. Figure 2 shows the sectional view of the fabricated brick moulding machine, while Figure 3 represents the isometric view of the machine.

\section{Results and discussions.}

A locally fabricated manually operated multiple brick moulding machine was designed and constructed. The machine was put to test for about 2 hours, and was able to turn out an average of about 40 bricks. This confirms its competiveness with an electrically operated machine. The output is a total of four bricks at a time with standard specification of $215 \times 102.5 \times 65 \mathrm{~mm}$, which is in compliance with internationally accepted standard, particularly the BS Standard. The cover of the mould boxes was used for ramming and compaction instead of an electricmotor controlled process. The moulded bricks were furnacedried and cured using a coke-fired furnace after sun drying. The machine was fabricated with the available facilities in the workshop, i.e. the lathe, the sensitive drilling machine, the milling machine and the arc-welding machine. Mild steel was used for most of the machine component because of its relative ease of machining, low cost and availability. The machine can be used in both rural and urban areas, especially in Nigeria where there is erratic power supply. The moulded bricks are strong and reasonably hard especially after drying and curing. These made them suitable for use for internal and external walls, building foundations, pavements, and other civil engineering structural construction purposes without plastering. Thus, it is more economical, environmental friendly and less hazardous especially in terms of fire outbreak to use the clay bricks instead of conventional cement blocks for most of our construction work.

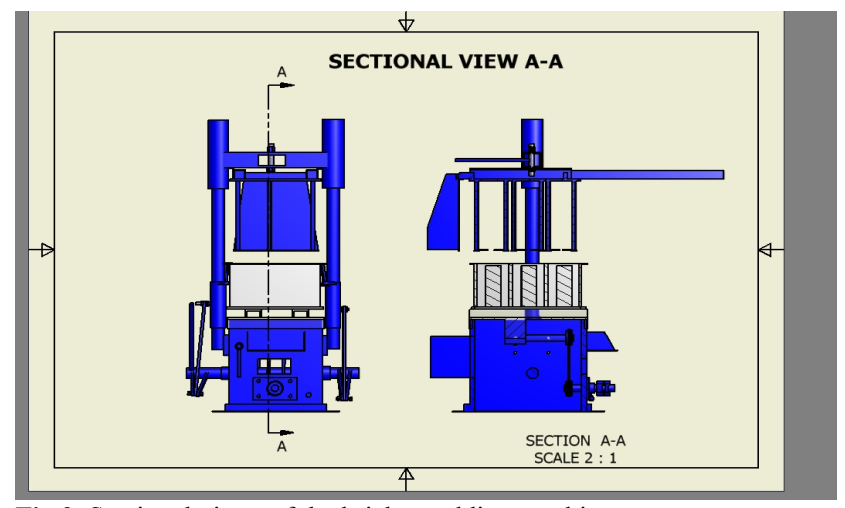

Fig.2. Sectional views of the brick moulding machine

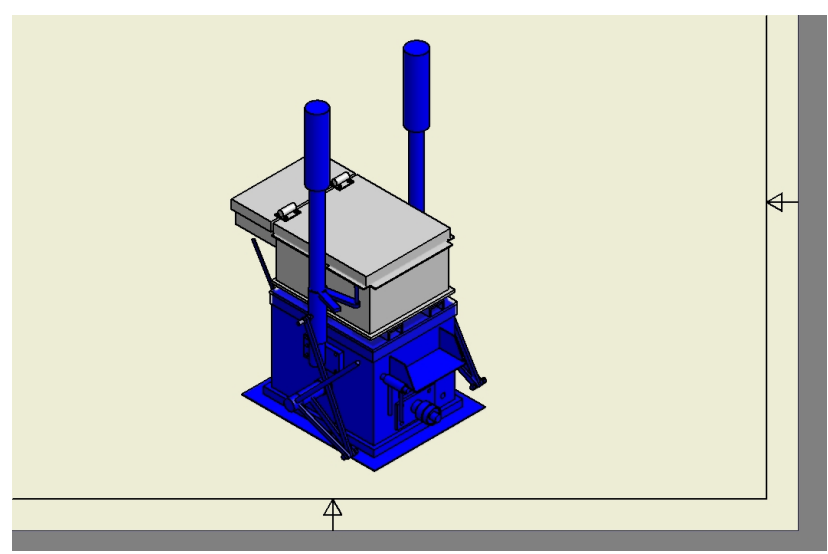

Fig. 3. Isometric view of the brick moulding machine

\section{Conclusions}

Clay brick moulding machine can be produced from locally available mild steel to meet the specifications of imported moulding machine. The moulded bricks are reasonable strong, hard, and environmental friendly. Thus, they are suitable for use for pavements, walls and other structural purposes.

\section{Acknowledgements}

The authors wish to express their appreciation to their technical staff of Mechanical and Civil Engineering Department, University of Ilorin, Ilorin, Nigeria for their support during the course of this work. 


\section{References}

1. M.F. Ashby and R.H. Jones, "Engineering Materials 1: An Introduction to their properties and applications", 2nd edition, Butterworth Heinemann, Oxford, (2002).

2. J. Keddie and W. Cleghorr, "Bricks manufacturing in developing countries", Scottish Academic Press Ltd., Edinburgh, (1980).

3. R.S. Khurmi, "Applied mechanics Strength of Materials", S. Chand \& Company Ltd., Ram Nagar, New Delhi 110-055, (2005).

4. R.S. Khurmi and J.K. Gupta, "A textbook of machine design", Eurasia Publishing House Ltd., Ram Nagar, New Delhi, (2004).
5. B.C. Harray, "Clay bricks production", Eyre and Spottiswood Publications Ltd. 5th Edition, pp 221-233, (1992).

6. J.J. Roberts, A.K. Tuvey, W.B. Granston and A.W. Beeby, "Concrete Masonry designer's Handbook', Eyre \& Spottiswood Publications Ltd., Leather Head, Surrey. pp. 33, (1992).

7. H.S. Stein, "Construction glossary, an encyclopaedic reference", John Wiley and Sons Inc., New York. 2nd Edition, pp 4 - 16, (1990).

8. J.L. Weinberg "Building Acts", Microsoft Encarta 2009, Microsoft Corporation, (2008). 